\title{
Investigation of Different Values of Nanoimidacloprid for Control of Tobacco Aphids Myzuspersicaenicotianaein Laboratory
}

Assemi $\mathrm{H}^{*}$, Sajjadi A and Naghizadeh $\mathrm{F}$

Tirtash Research and Education Center, Behshahr, Iran

*Corresponding author: Assemi H, Tirtash Research and Education Center, Behshahr, Iran, E-mail: Hoda_Assemi@yahoo.com

Rec date: July 20, 2014, Acc date: Sep 30, 2014, Pub date: Oct 02, 2014

Copyright: (C) 2014 Assemi $\mathrm{H}$, et al. This is an open-access article distributed under the terms of the Creative Commons Attribution License, which permits unrestricted use, distribution, and reproduction in any medium, provided the original author and source are credited.

\begin{abstract}
Nano-insecticides which have economic importance and high health because of its greater effectiveness compared with conventional varieties of crops are used to combat pests. Another subject which need to be researched and development in the field of nano-pesticides is pest resistance to pesticides. This phenomenon seriously reduced the number of pesticides. In this regard, in order to evaluate the performance of various amounts of nanoimidacloprid for control tobacco aphids Myzuspersicaenicotianae use emulsion-solvent evaporation was poison Nano. Transmission electron microscopy (TEM) was used to confirm the nano-size of pesticide. Nanoimidacloprid and Imidacloprid tobacco leaves at different concentrations (20, 35.156, 49.773, 70.469, 99.77, 141.253 and $200 \mathrm{mg}$ ) were immersed for two seconds. After drying, the leaves, the fifth in four replicates of 30 nymphs in laboratory conditions at a temperature of $25 \pm 2$ degrees Celsius, relative humidity $5 \pm 65 \%$ of were released. POLO-PC software analysis was performed to determine the extent of LC50 and LT50.Results indicate that the LC50 levels for Imidacloprid $69.623 \mu \mathrm{l} / \mathrm{ml}$ after 72 hours and Nanoimidacloprid, 37.919 (1/8 times less than that of conventional pesticides) was achieved after 24 hours. The results showed that Nano-pesticidesare more effective and toxic to insect pests, compared to conventional insecticides.
\end{abstract}

Keywords: Pest resistance;

Myzuspersicaenicotianae; Nanoimidacloprid

\section{Introduction}

Tobacco is considered one of the tobacco aphid pests. Plant protection researcher efforts on reducing the use of chemicals, especially in products that are used by humans. Numerous applications of nanotechnology in agriculture, food industry and animal science are discussed. Familiarity with the increasing progress in the field of nanotechnology and Nano-scale multiple pesticides and a wide variety of applications in various scientific and industrial trends, which has led companies to improve the profile of their products as producer of pesticides, looking to utilization. Negahbanproducedin [1] a pesticide plant Nancapsulate micro emulsion formulated as powders, pills and spray for pests of agricultural uses.

\section{Materials and Methods}

The survey in 2012 in the laboratory was done to determine the efficacy of different doses of Nanoimidacloprid control of tobacco aphid, Myzuspersicaenicotianaein Tirtash Research and Education Center, Behshahr. In this study, Nano-pesticide was obtained using emulsion- solvent evaporation. Transmission electron microscopy (TEM) was used to confirm the nano-size of pesticide (Figure 1). In this study, the highest and lowest lethal dose was determined Nanoimidicloprid. Concentrations between the minimum and maximum concentrations were calculated using the logarithmic. Nanoimidacloprid and Imidacloprid tobacco leaves at different concentrations $(20,35.156,49.773,70.469,99.77,141.253$ and 200 $\mathrm{mg}$ ) were immersed for two seconds. After drying, the leaves, the fifth in four replicates of 30 nymphs in laboratory conditions at a temperature of $2 \pm 25$ degrees Celsius, relative humidity $65 \pm 5 \%$ and photoperiod of 14 hours light and 10 hours of darkness were released. POLO-PC software results were analyzed to determine the extent of LC50 and LT50.

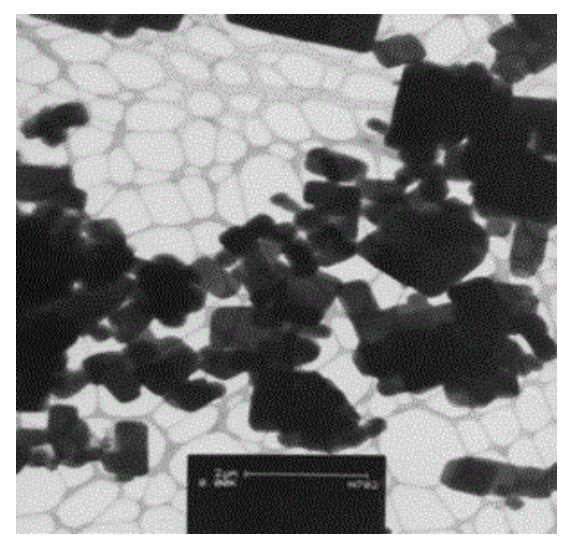

Figure 1: TEM image of Nano-imidacloprid.

\section{Results and Discussion}

According to the results, Nano-imidacloprid caused about 20 and 80 percent of deaths in the lowest and highest concentrations (100 and $300 \mathrm{mg}$ ). LC50 levels for Imidacloprid was obtained $2.56 \mathrm{mg}$ after 72 hours and the highest dose of $0.512 \mathrm{mg}$ of nano-Imidaclopridat, i.e. around five times fewer pesticides was achieved after 24 hours (Tables 1 and 2). The results showed that nano-pesticides it is more effective in comparison of insecticides and fifth instar are more toxic. As can be 
Citation: Assemi H, Sajjadi A, Naghizadeh F (2014) Investigation of Different Values of Nanoimidacloprid for Control of Tobacco Aphids Myzuspersicaenicotianaein Laboratory. Agrotechnol 3: 128. doi:10.4172/2168-9881.1000128

Page 2 of 3

seen in Table 3 Analysis of variance of the effect of Nano-pesticides and insecticides are significant at the one percent level. Table 4 shows the percentage of aphid mortality impact of insecticides and pesticides nanoparticles in vitro and mean values.

\begin{tabular}{|c|c|c|c|c|c|c|c|}
\hline \multirow{2}{*}{$\begin{array}{l}\text { Chemical } \\
\text { tested }\end{array}$} & \multirow{2}{*}{$\begin{array}{l}\begin{array}{l}\text { Lethal } \\
\text { concentration } \\
\text { s }\end{array} \\
(\mu / \mathrm{ml})\end{array}$} & \multirow{2}{*}{$\begin{array}{l}\text { Mortality estimator equation } \\
\text { In terms of amounts of the toxin } \\
\text { and Nanvsm }\end{array}$} & \multicolumn{3}{|c|}{ LT (days) } & \multirow{2}{*}{$\begin{array}{l}\text { Slope } \pm \text { SE } \\
\left(X^{2}\right)\end{array}$} & \multirow{2}{*}{ Chi-Square } \\
\hline & & & $\mathbf{L} \mathbf{T}_{10}$ & $\mathbf{L} \mathbf{T}_{50}$ & $\mathbf{L} \mathbf{T}_{90}$ & & \\
\hline Imidacloprid & 70.469 & $Y=3.057 X+2.187$ & 3.188 & 8.37 & 21.97 & $3.057 \pm 0.403$ & 0.206 \\
\hline Nanoimidacloprid & 35.156 & $Y=2.77 X+2.649$ & 20.691 & 7.132 & 20.691 & $2.77 \pm 0.305$ & 0.226 \\
\hline
\end{tabular}

Table 1: Effect of Nanoimidacloprid Probit analysis of the data and common insecticides on the tobacco aphid.

\begin{tabular}{|c|c|c|c|c|c|c|}
\hline \multirow{2}{*}{ Chemical pesticides tested } & \multirow{2}{*}{$\begin{array}{l}\text { Mortality estimator } \\
\text { equation }\end{array}$} & \multicolumn{3}{|l|}{ LC } & \multirow{2}{*}{$\begin{array}{l}\text { Slope } \pm \text { SE } \\
\left(X^{2}\right)\end{array}$} & \multirow[t]{2}{*}{ Chi-Square } \\
\hline & & $\mathbf{L C}_{10}$ & $\mathrm{LC}_{50}$ & $\mathbf{L C}_{90}$ & & \\
\hline Imidacloprid & $Y=2.025 X+1.24$ & 16.233 & 69.623 & 298.623 & $2.025 \pm 0.187$ & 0.48 \\
\hline Nanoimidacloprid & $Y=1.64 X+2.45$ & 6.27 & 37.919 & 229.153 & $2.77 \pm 0.190$ & 0.21 \\
\hline
\end{tabular}

Table 2: Determination of lethal doses of insecticides commonly used Nanoimidacloprid and the tobacco aphid.

According to Larrouturou [2] sense of ethics, reflecting man's desire to enable various generations to live together harmoniously and decently drives us to analyze the moral foundations of discoveries through open debate, turning the scientist back into a concerned citizen. In the field of Nano-science, the perspective of mastering complexity at a tiny scale is used sometimes as a fallacious argument based on fear. Even if ill founded, such negative attitudes must be taken into account: engaging in public debate about ethics is a moral obligation for scientists. A first step in this debate is undoubtedly measuring and recognizing the huge gap between our understanding of a few functions at the Nano-metric scale and the complexity of life. The new nanotechnology with materials having unique properties than their macroscopic or bulk counterparts, has promised applications in various fields. The essence of nanotechnology is the ability to work at the molecular level, atom by atom, to create large structures with fundamentally new molecular organization [3-5]. The aim is to exploit these properties by gaining control of structures and devices at atomic, molecular, and supra molecular levels and to learn to efficiently manufacture and use these devices $[6,7]$.

\begin{tabular}{|l|l|l|l|}
\hline \multirow{2}{*}{$\begin{array}{l}\text { Sources } \\
\text { changes }\end{array}$} & \multirow{2}{*}{$\begin{array}{l}\text { Degrees } \\
\text { freedom }\end{array}$} & \multicolumn{2}{|l|}{ of } \\
\cline { 3 - 4 } & & \multicolumn{2}{|l|}{ Nanoimidacloprid } \\
\cline { 3 - 4 } & & Dead nymphs & $\%$ control \\
\hline Treatment & 13 & 203.14 & 2443.4 \\
\hline Error & 42 & 0.47 & 2.36 \\
\hline CV & & 3.95 & 3.03 \\
\hline
\end{tabular}

Table 3: Analysis of variance of the effect of Nano-pesticides and insecticides on the tobacco aphid.

\begin{tabular}{|c|c|c|c|}
\hline Pesticides tested & $\begin{array}{l}\text { Pesticide } \\
\text { concentrations } \\
\text { tested }(\mu \mathrm{l} / \mathrm{ml})\end{array}$ & $\begin{array}{l}\text { The number of } \\
\text { dead after } \\
\text { seven days }\end{array}$ & $\begin{array}{l}\text { Average } \\
\text { percentage } \\
\text { mortality (\%) }\end{array}$ \\
\hline \multirow{7}{*}{ Imidacloprid } & 25 & $8.33 i$ & $21.11 \mathrm{i}$ \\
\hline & 35.156 & 9 hi & $22.33 \mathrm{k}$ \\
\hline & 49.773 & $9.66 \mathrm{gh}$ & $24.44 \mathrm{~h}$ \\
\hline & 70.469 & $10.66 \mathrm{~g}$ & $28.88 \mathrm{~g}$ \\
\hline & 99.77 & $14.33 \mathrm{f}$ & $41.11 \mathrm{f}$ \\
\hline & 141.253 & $21.66 \mathrm{bc}$ & $65.55 \mathrm{c}$ \\
\hline & 200 & $29 a$ & $90 \mathrm{~b}$ \\
\hline \multirow{7}{*}{ Nanoimidacloprid } & 25 & $10.66 \mathrm{f}$ & $28.88 \mathrm{f}$ \\
\hline & 35.156 & $17.33 \mathrm{e}$ & $51.11 \mathrm{e}$ \\
\hline & 49.773 & $19 \mathrm{~d}$ & $56.66 \mathrm{~d}$ \\
\hline & 70.469 & $19.66 \mathrm{~d}$ & $58.88 \mathrm{~d}$ \\
\hline & 99.77 & 20.66 bc & $62.22 \mathrm{~cd}$ \\
\hline & 141.253 & $22 b$ & $66.66 \mathrm{c}$ \\
\hline & 200 & $30 a$ & $100 \mathrm{a}$ \\
\hline
\end{tabular}

Table 4: Percentage of aphid mortality impact of Nano-pesticides and insecticides in vitro.

\section{Conclusion}

The results showed that nano-imidacloprid compared with conventional insecticides $t$ is more effective and more toxic to insect pests. 
Citation: Assemi H, Sajjadi A, Naghizadeh F (2014) Investigation of Different Values of Nanoimidacloprid for Control of Tobacco Aphids Myzuspersicaenicotianaein Laboratory. Agrotechnol 3: 128. doi:10.4172/2168-9881.1000128

Page 3 of 3

\section{References}

1. Bhattacharyya A, Bhaumik A, Rani PU, Mandal S, Epidi TT (2010) Nano-particles-A recent approach to insect pest control. Asian Journal of Biotechnology 9: 14 .

2. Larrouturou L (2005) The nanosciences. Centre national De La Recherché Science, 42.

3. Carey DJR (1993) Applied demography for biologists with special emphasis on insects. Oxford University Press, New York: 206.

4. Guan H, Chi D, Yu J, Li H (2010) Dynamics of residues from a novel nano-imidacloprid formulation in soyabean fields. Crop Protection 29: 942-946.
5. Hemingway J1, Ranson H (2000) Insecticide resistance in insect vectors of human disease. Annu Rev Entomol 45: 371-391.

6. Schulze CA (2008) Nanotoxicology 2: 51-61.

7. Spielmann H, Genschow E, Leibsch M, Halle W (2001) Report on the ICCVAM workshop on in vitro methods for assessing acute systemic toxicity", ALTEX-AL TI 18: 115-116. 